\title{
НАРОДНЫЕ И АПОКРИФИЧЕСКИЕ МОТИВЫ РОЖДЕСТВЕНСКОГО ЦИКЛА, ОТРАЖЕННЫЕ В УГЛЯНСКИХ РУКОПИСЯХ ВТОРОЙ ПОЛОВИНЫ ХVII ВЕКА
}

Материал для нашего исследования мы черпали в двух рукописных кириллических сборниках проповедей, толкований евангельских перикоп, поучений и экземплумов, которые возникли в конце XVII века в православном монастыре в селе Угля в современной Закарпатской области Украины. Первый сборник под названием Углянское учительное евангелие содержит переводы и толкования евангельских перикоп. Второй сборник называется Углянский сборник Ключ и состоит из проповедей, поучений на различные праздники церковного года, толкования, легенды и экземлумы. Автор рукописи Ключ использовал различные источники, которые были доступны и обычны в то время в центральноевропейской среде, находящейся под влиянием византийско-славянской культурно-обрядовой традиции, например, Gesta Romanorum, Лимонарий, Физиолог, Диоптра и другие. Обе рукописи написаны на церковнославянском языке с заимствованиями из местной языковой среды, особенно из русинско-украинских диалектов подкарпатско-русинского региона, заимствованиями из контактной диалектной среды восточнославянских диалектов, из польского, венгерского и румынского языков. В отличие от Углянского учительного евангелия, сборник Ключ содержит гораздо больше народных языковых заимствований. Этому факту мы не будем уделять внимание в настоящей статье.

Несмотря на хорошо сохранившееся до наших дней культурное наследие пограничного между славянским Востоком и Западом ареала, которое включает в себя десятки рукописных книг литургического и окололитургического характера, в настоящее время проводится крайне мало исследований, касающихся этого самого культурного наследия ${ }^{1}$. До настоящего време-

\footnotetext{
${ }^{1}$ Важнейшей работой по указанной проблематике является хрестоматия: P. ŽEŇUCH, Источники византийско-славянской традиции и культуры в Словакии / Praтепе $k$ byzantsko-slovanskej tradícii a kultúre na Slovensku, Bratislava-Roma 2013. Проблематикой исследования кириллической гомилетической и экзегетической традиции занимается и польская исследовательница Г. ЧуБА. Сf. е.g. Г. ЧуБА, Украӥнські рукописні учительні Євангелія. Дослідження, каталог, описи, Київ-Львов 2011.
} 
ни углянские рукописи не были полностью изучены и даже опубликованы, хотя они представляют собой большой интерес для исследователей диалектологии, культурно-религиозной традиции, истории литературы и других дисциплин. Данные рукописи содержат уникальные сюжеты и мотивы, которые сохранились до нашего времени только в этих конкретных памятниках. Таким образом, их значение заключается также и в том, что смогли сохранить уникальную прозаическую и легендарную традицию, которая непрерывно развивалась в обеих частях культурно-религиозного славянского мира.

Исследуемые рукописи хранятся в архиве Национального музея в Праге. Их описал и частично издавал исследователь карпатской словесности Юлиан Яворский в первой половине XX века ${ }^{2}$, позднее краткое описание им дали Йозеф Вашица и Йозеф Вайс ${ }^{3}$. В настоящее время эти рукописи незаслуженно забыты, исследованием данной рукописной традиции карпатского происхождения систематически начали заниматься в Институте славистики им. Яна Станислава Словацкой академии наук только с недавних пор. Этот факт обуславливает и методику исследования: до тех пор, пока не существует обработанный корпус текстов карпатского происхождения, текстологическое исследование не представляется возможным ${ }^{4}$.

Подкарпатская Русь второй половины XVII века представляет собой культурный феномен, так как располагается на границе между двумя славянскими конгломератами, называемыми Slavia Latina и Slavia Byzantina. Эти славянские конгломераты отличаются друг от друга языком, но прежде всего церковными обрядами и культурной традицией. Данная область интересна для исследователя тем, как в ней совмещаются и взаимно влияют друг на друга различные культурно-религиозные традиции и языковые контексты межкультурной и межэтнической среды карпатского региона. Подобное взаимовлияние и в настоящее время отражается на всех уровнях культурной жизни людей, в том числе на уровне языка и понятийного аппарата, что находит подтверждение в памятниках письменности, возникших в исследуемой среде. Духовная культура в регионе под Карпатами, находясь под влиянием византийской традиции, вбирала в себя элементы обоих конгломератов, поэтому благодаря пограничному расположению ее можно воспринимать как самостоятельную культурную единицу. Особо важным фак-

\footnotetext{
${ }^{2}$ Сf. Ю.А. Яворский, Ветхозавптныя библейскія сказанія въ карпаторусской церковноучительной обработкпь конца XVII-го впкка, Ужгород-Прага 1927; IDEм, Повъьсти изб "Gesta Romanorum» въ карпаторусской обработкп конца XVII-го впка, Прага 1929; IDEм, Новыя рукописныя находки въ области старинной карпаторусской письменности XVI-XVIII втоковъ, Прага 1931.

${ }^{3}$ J. VAšıcA, J. VAJs, Soupis staroslovanských rukopisů Národního musea v Praze, Praha 1957.

${ }^{4}$ Учитывая этот факт, автор данной статьи в качестве диссертационной работы готовит комментированное издание обеих углянских рукописей XVII века.
} 
тором для формирования и развития самостоятельной духовной культуры в этом регионе стала некоторая изолированность бывшей Мукачевской епархии от остальной культурно-конфессиональной среды ${ }^{5}$. Конечно, на территории бывшей Мукачевской епархии существовали монастыри и при них школы, духовные семинарии, хотя общий уровень образования все равно стереотипно считается низким ${ }^{6}$. Молодое поколение обычно перенимало опыт старших; чтению, письму и церковному пению их в основном обучали священники, местные грамотные люди и учителя. Несмотря на то, что крепостными были и прихожане, и многие священники, высокий уровень языковой и богословской подготовки последних обеспечил существование собственной обширной письменной традиции, в рамках которой создавались как литургические книги (литургиконы, триодионы, минеи, требники, псалтыри, апостолы, евангелиарии и другие), так и рукописные сборники окололитургического характера: проповеди, сборники заметок исторического характера и изложений истории церкви, правила церковной жизни, толкования и поучения, апокрифы, легенды, повести и сборники рассказов о житиях святых и происхождении праздников, о происхождении и природе мира и подобные.

Как правило, эти книги являются списками с более старых источников, но не исключены и стилизации, компиляции и переводы с других, в том числе латинских и греческих, оригиналов. Чаще всего подобным образом возникали сборники экзегетических текстов с переводами и толкованиями для простых людей, записанные на местном народном языке кириллическим шрифтом. Среди таких сборников чаще всего встречаются переводы литургических евангельских перикоп, за которыми следуют пространные толкования и поучения, которые использовались священниками как материал для подготовки к проповеди или читались в храме вместо проповеди.

\footnotetext{
${ }^{5}$ C. VASIL, Kanonické pramene byzantsko-slovanskej katolíckej cirkvi v Mukačevskej a Prešovskej eparchii v porovnanís Kódexom kánonov východných cirkví, Trnava 2000.

${ }^{6}$ С языковой и культурной идентичностью верующих иеркви византийского обряда в Словакии тесно связан и их уровень образования. Большое количество памятников письменности, которые возникли в среде византийского обряда в Мукачевской епархии на церковнославянском, латинском, словацком, русинском, украинском, польском, венгерском и немеиком языках, свидетельствует не только об этнической принадлежности писарей, но и об их высоком уровне образования, который они получили не только за границей Венгерского королевства (на Украине, в Польше, Сербии), но и в домашней среде, например, в школах при монастырях латинского и византийско-славянского обряда, а также в различных деревенских и городских школах и училищах, которые посещали одаренные прихожане византийской иеркви. Именно они интересуются и всегда интересовались образованием. Обычно потом они становились священниками или учителями в домашней конфессиональной среде, если только не подвергались давлению со стороны латинского пространства. Результатом незнания этих обстоятельств являются повторяющиеся и сегодня стереотипные взгляды на духовенство, учителей и канторов в среде византийского обряда как на необразованных. (Р. ŽEŇUсH, Источники византийско-славянской... p. 84.)
} 
Развитие гомилетической традиции, находящейся под влиянием неканонических (апокрифических) сочинений, хорошо видно в проповедях на праздник Рождества Христова. Среди нескольких толкований евангельских перикоп в Углянском учительном евангелии находится один такой текст, а в сборнике Ключ - два. В обеих рукописях встречается мотив, известный из Сказания Афродитиана. Сказание Афродитиана в славянском контексте появилось в XII-XIII вв. в качестве перевода с греческого оригинала7. Эдуард Братке высказывает предположение о происхождении сказания в Малой Азии или Сирии во второй половине IV в., где это мифологическое повествование в результате смешения религиозных элементов различного происхождения и характера трансформировалось в позднейшую синкретическую версию. По мнению исследователя, сказание, написанное на туманном языке предсказаний оракулов, возникло как результат хорошо продуманной христианской апологетики ${ }^{8}$. Другой исследователь сказания, АлександрБобров, утверждает, что Сказание относится к общему фонду памятников литературы восточных и южных славян, встречается не только в греческих и древнерусских, но и в сербских, болгарских, молдавских, украинских и румынских рукописях 9 .

Изучением Сказания Абродитиана занимались многие ученые. Среди них Н.С. Тихонравов, П.Е. Щеголев, А.Н. Пыпин, И.Я. Порфирьев, И. Франко, Й. Поливка, каждый из которых издал хотя бы один вариант сказания. Объемную статью о сказании и его функционировании в украинской традиции посвятила В.П. Адрианова-Перетц. Главным исследователем сказания в настоящее время является уже упомянутый А.Г. Бобров, который проделал огромную работу, связанную с поиском и анализом всех возможных списков сказания. В своей монографии Апокрифическое Сказание Аळродитиана в литературе и книжности Древней Руси он изучил свыше 90 списков, но списки сказания, содержащиеся в углянских рукописях, ему не были доступны.

Известно, что Сказание Афродитиана было занесено в русские списки «книг истинных и ложных» с подачи Максима Грека, который строго осудил сказание, направив на него Обличеніе и опроверженіе лживаго писанія зломудраго Аøродитіана персянина. Максим Грек рекомендует рассматривать книги на предмет их истинности, проверять, не нарушают ли

\footnotetext{
${ }^{7}$ Существуют два перевода Сказания Афродитиана. Первый был сделан в домонгольское время на территории Южной Руси, древнейший список относится к XIII в. Второй перевод, согласно предположению П.Е. Щеголева, выполнен в Константинополе или на Афоне в кон. XIV - нач. XV в. Во втором переводе текст озаглавлен Повесть Афродитиана, а не Сказание, и авторство приписывается Филиппу Пресвитеру.

${ }^{8}$ E. Bratke, Das sogenannte Religiongeshpräch am Hof der Sasaniden, Leipzig 1899. Здесь и далее цитируется по А.Г. БоБров, Апокрифическое Сказание Афродитиана в титературе и книжности Древней Руси, Санкт-Петербург 1994.

${ }^{9}$ Ibidem, p. 19.
} 
они догматы веры, и вообще не всякимъ вптромғ ученія увлекаться ${ }^{10}$. Он также отмечает, что произведение весьма почитаемо у простых верующих, недугующихъ недостаточнымъ пониманіемъ боговдохновенныхъ писаній Максим Грек отмечал, что автор сказания не относится к числу авторитетных христианских писателей, многое в произведении не согласуется со Священным Писанием и противоречит историческим фактам, внутренне оно нелогично и противоречиво и в нем встречаются еретические мысли ${ }^{12}$. В итоге текст был исключен из круга Уставных чтениц̆, но индивидуальное чтение его не запрещалось, и, судя по всему, текст не приравнивался к «книгам ложным и отреченным» - апокрифам. Рассмотрев дальнейшую историю сказания, А.Г. Бобров приходит к выводу, что в середине XVI-XVII вв. постепенно утверждается представление о Сказании Афродитиана как об апокрифическом произведении, что приводит к резкому уменьшению количества его списков ${ }^{13}$. Однако даже резкая критика Максима Грека не сломила полностью интерес читателей к Сказанию Афродитиана, и его вторая часть, описывающая путешествие волхвов, продолжала влиять даже на церковные слова на праздник Рождества Христова. Именно мотив прихода трех царей находится в различных вариантах гомилетических произведений в углянских рукописях.

В рукописи IX С 19 (Углянское учительное евангелие) находится пропо-

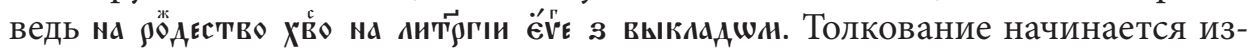
далека, от родителей Христовых, и содержит стройное выверенное повествование, согласующееся со Священным Писанием. Вторая часть рукописи, озаглавленная w нћаิкй нүдљъцй является словом на Рождество Христово о пришествии волхвов. Специфика текста обусловлена спецификой самого памятника: это учительное евангелие, здесь не может быть неточностей в изложении и толковании библейских событий, а автор отличается последовательностью повествования. Кроме того, автор объясняет административное устройство Иудеи во время рождения Христа, что придает тексту последовательность и достоверность:

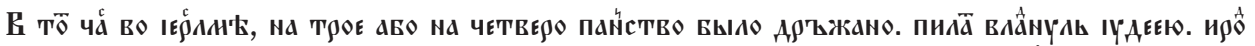

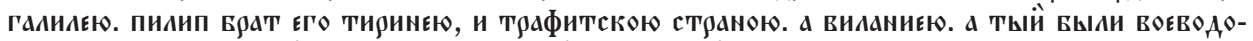

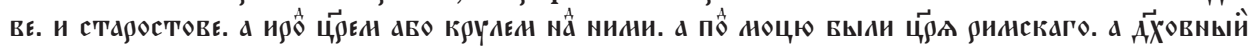

\footnotetext{
${ }^{10}$ М. Грек, Сочинения преподобнаго Максима Грека въ русскомъ переводю. Часть третья, Свято-Троицкая Сергіева лавра 1911, р. 82.

${ }^{11}$ Ibidem.

${ }_{12}$ М. Грек оспаривает даже такие подробности, как рассказ о том, что младенец Христос играл и смеялся, на что возражает, что младенец сей не был подобен неразумным младенцам, а был совершенный Бог и нрав его не был младенческим. Вообще, утверждение, что Христос никогда не смеялся, свойственно про русскую культуру в целом (cf. е.g. В.В. РозАнов, Темный лик. Метафизика христианства, Санкт-Петербург 1911).

${ }^{13}$ А.Г. БоьРов, Апокрифическое Сказание Афродитиана... p. 87.
} 


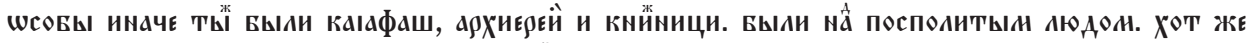

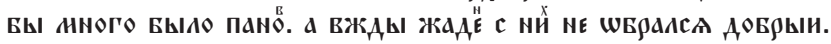

Характерной особенностью этого списка является эпизод, когда волхвы, пришедшие в Иерусалим, стали спрашивать людей, где родился «царь

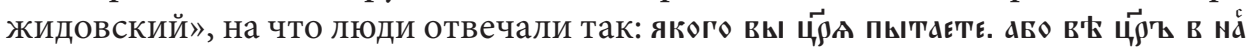

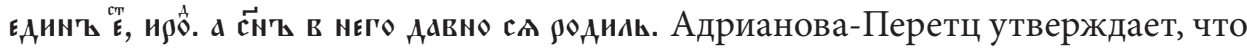
упоминание о сыне Ирода является характерной чертой именно украинских переработок Слова о пришествии волхвов ${ }^{14}$. Указание на место происхож-

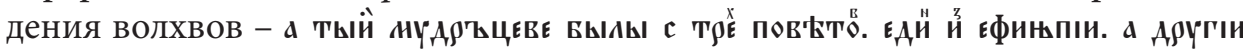
й сарıи. а төєтіи й аравıи - позднейшее дополнение, встречается именно в

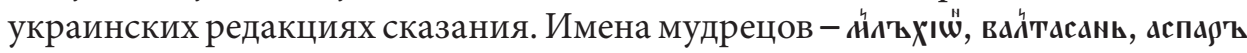
- традиция скорее западная, латинская. Также довольно редок эпизод, когда волхвы сидят по приказанию рассерженного Ирода в темнице, а их разговор подслушивает стражник. Интереснен факт, что вифлеемская звезда, доведя

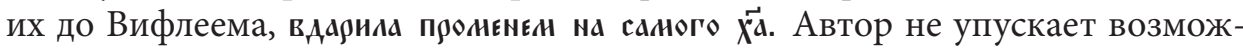
ности прямо по ходу проповеди объяснить слушателям непонятные места: говоря, что волхвы принесли в дар Христу золото как царю, кадило как богу и миро как несмертельному, между делом объясняет

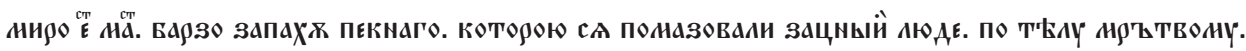
АБЫ НЕ СНОЪАТАЛ. АБЫ НЕ ГНИАО.

В заключении повествования автор использует риторические приемы:

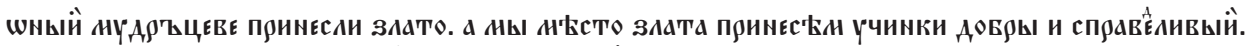

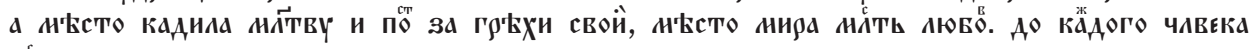
хе́тіланского.

Рукопись IX C 18, или Углянский сборник Ключ, - это сборник евангельских толкований преимущественно религиозно-дидактической тематики, содержит разнообразные поучения и повести, заимствованные из духовных и светских источников. В проповеди на Рождество Христово также встречается мотив, ведущий свое происхождение от Сказания Аøродитиана. Несмотря на то, что рукописи учительного Евангелия и сборника Ключ были созданы примерно в одно время в Углянском монастыре и даже сшиты под одним переплетом ${ }^{15}$, речь идет о двух совершенно разных редакциях Сказания Аøродитиана. С большой вероятностью можно утверждать, что при их создании были использованы разные источники. Характерным в этой связи нам представляется описание волхвов:

\footnotetext{
${ }^{14}$ В.П. АДРИАНОВА-ПЕРЕТЦ, Из истории русско-украинских литературных связей в ХVIII веке, [in:] Исследования и материаль по древнерусской литературе, Москва 1961, р. 269.

${ }^{15}$ Ю.А. Яворский, Новыя рукописныя находки... р. 43.
} 


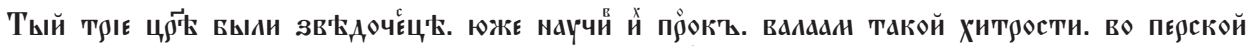

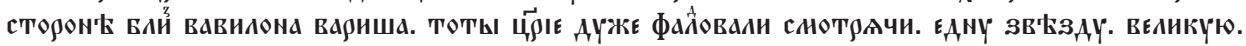

Дары, принесенные волхвами младенцу Иисусу, также отличаются от общей традиции:

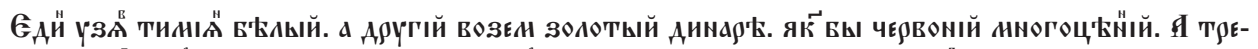

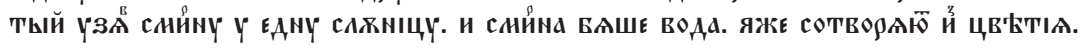

В тексте дана подробная информация о волхвах: им по сорок лет, они говорят на халдейском языке и идут в Вифлеем не одни, а в сопровождении тридцатилетнего юноши-писаря Изуграфа, который впоследствии описал (возможно, что и нарисовал) Богородицу и записал разговоры волхвов. Этот мотив встречается только в некоторых редакциях Сказания, фигура же Изуграфа не была известна из ранее исследованных вариантов сказания и в нашем источнике встречается впервые ${ }^{16}$.

В Иерусалиме волхвы решают пойти спросить Ирода о месте рождения Иисуса Христа Назарянина, и Ирод им отвечает, что Младенец, по словам пророков, должен родиться в Вифлееме. Волхвы уходят из Иерусалима без какихлибо проблем, а путеводная звезда снова выходит и светит им. Этот факт достаточно красноречиво свидетельствует о том, что автор, а может быть и переписчик, не были близко знакомы с обстоятельствами Рождества Христова.

Несмотря на то, что в начале данной редакции Ирод ошибочно не представляет опасности, в тексте-вставке Изуграфа он все же рассердился, когда волхвы не пришли к нему после поклонения Христу и решил избавиться от младенцев возрастом до трех лет. Эпизод избиения младенцев изначально не должен входить в Сказание Афродитиана, ведь волхвы ничего не знали о кровопролитии в Иудее, так как совершилось оно много позднее, когда Ирод разгадал обман.

Отличительной чертой редакции Сказания Аøродитиана, записанной в Углянском сборнике Ключ, является следующий эпизод. Волхвы, или как их здесь называют, цари, ходили поклониться Иисусу и Богородице по очереди. Первый, зайдя, на руках девы Марии вида'

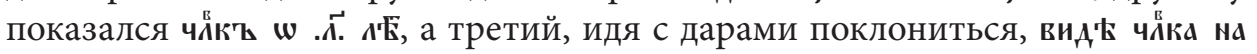

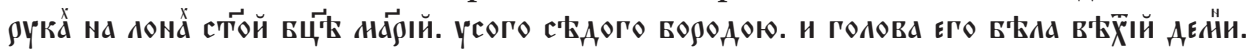
Данный мотив до сих пор еще не встречался в рамках исследования Сказания Аøродитиана. Такой образ Святой Троицы на руках Богородицы в народной культуре встречается очень редко.

\footnotetext{
${ }^{16}$ Несмотря на то, что этот мотив не является распространенным в письменной традиции, он встречается в иконографии. В качестве примера можно привести икону Собор Богоматери Варваринской церкви в Пскове, где около волхвов изображена и фигура писаря (или человека с книгой). За это наблюдение автор сердечно благодарит доцента Российского государственного гуманитарного университета (РГГУ) Н.В. Квливидзе.
} 
Также в тексте находятся слова Богородицы, обращенные к Сыну:

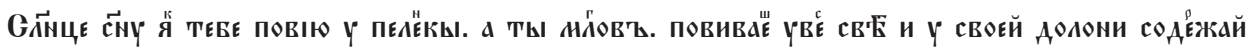

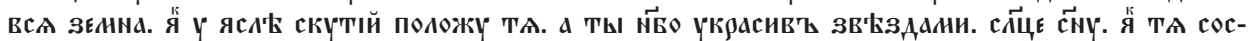

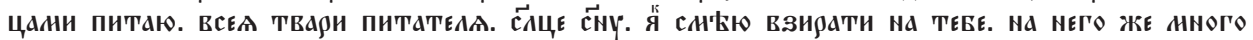

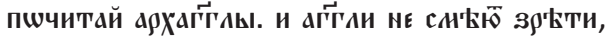

которые, возможно, берут свое происхождение в текстах, связанных с проведением богослужебных обрядов на праздник Рождества Христова. ${ }^{17}$

Второе поучение на Рождество Христово, содержащееся в Углянском сборнике Ключ, содержит больше народных мотивов. Повествование начинается с простого объяснения ветхозаветного сюжета об идолопоклонничестве, как люди, не видя Бога истинного и желая утолить свое стремление,

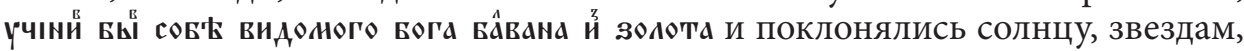
людям и Животным как богам. Тогда Бог Захотел ү тӧ АюА⿱艹

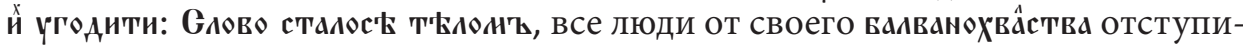
ли и расширилась по земле истинная вера, говорится в рукописи. В тексте поучения доступно объясняются элементарные религиозные положения, а также тексты молитв, кондаков и тропарей праздника Рождества Христова. Значение Рождества в тексте рукописи объясняется на противопоставлении ветхозаветного бога Богу истинному:

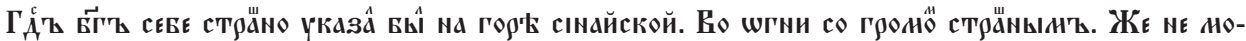
Гаи позирати. ани говодити изт Бгё̈ живӹ;

а о Рождестве Христа говорится следующее:

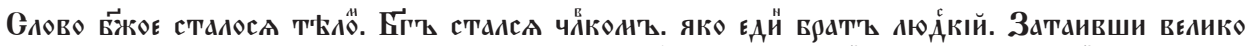

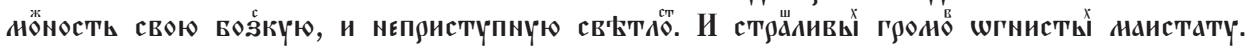

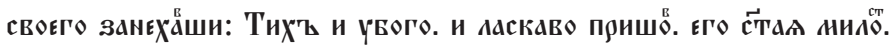

Несколько раз в тексте повторяется ключевая фраза, описывающая чудо Рождества Христова и перемену ситуации в целом в лучшую сторону: Gлюво

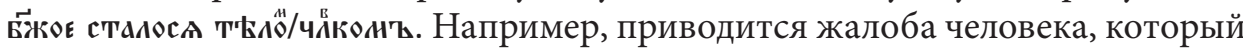
не имел ничего принести в жертву Богу, слюво Б̈жов стылосл т中лڤึ и Бог принял жертву своего Сына. Другой человек был болен, дли слово Б̈жов сталосл чйконъ и Он облегчил временные страдания людей и үсолөдй наш' Аочдсливыи мёзы жүры. Здесь мы встречаемся с достаточно известным мотивом, закрепленным в народной религиозности, который представляет Христа как второго Адама:

${ }^{17}$ Cf., e.g., с текстом Царских часов (час девятый, глас шестой): Dnes sa rodí z Panny ten, ktorý drží rukou celý svet. Podstatou nedotknutelného Boha ovijajú plachtami ako obyčajného človeka. Ten, ktorý na počiatku upevnil slovom nebesá, leží v jasliach. Ten, ktorý ludu na púšti zosielal mannu ako dáżd, sýti sa mliekom z pŕs. Mudrcov pozýva Ženích Cirkvi, ich dary prijima syn panny. Klaniame sa tvojmu narodeniu, Kriste, klaniame sa tvojmu narodeniu, Kriste, klaniame sa tvojmu narodeniu, Kriste, ukáž nám aj svoje božské bohozjavenia. 


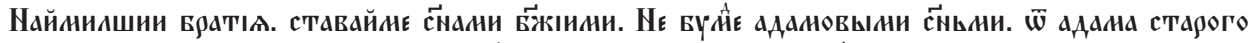

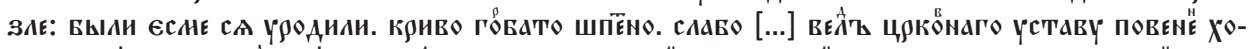
АИТТ Ч

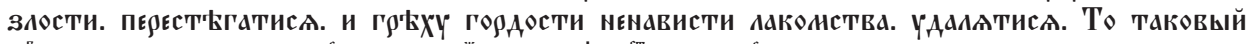
Ч

В Углянском учительном евангелии, которое использовалось при литургии в качестве проповедей, не допускается фактических ошибок, но в то же время встречаются тексты, не рекомендуемые к уставному чтению, которые окрашены апокрифическими, неканоническими и народными мотивами. В Углянском сборнике для чтения вне литургии, к которым мы относим сборник Ключ, апокрифы представлены в больших количествах, например, Сказание о Сивилле, Письмо Господне к дьяволу, об освобождении Адама в аду от nуm, Сказание о рыцаре и смерти и многие другие. Для духовной культуры Закарпатского ареала, находящейся под влиянием византийской церковной традиции, во второй половине XVII века характерно существование и функционирование неканонических текстов как в рамках канона, так и за его рамками.

Abstract. Folk and Apocryphal Motives of The Nativity Cycle, Reflected in Cyrillic Manuscripts
from Ugla Monastery from the $\mathbf{1}^{\text {th }}$ Century. This paper deals with Apocryphas of the nativity
cycle, particularly motives of the Three Wise Men arriving, which includes Afroditian's legend as
well, in cultural context of Transcarpatia, which is a border area between Slavia latina and Slavia byz-
antina. The datas for study were two cyrillic manuscripts from Ugla monastery from the $17^{\text {th }}$ century.

Ключевые слова: кириллические рукописи, апокриф, Сказание Афродитиана.

Keywords: Cyrillic manuscripts, Apocrypha, Afroditian's legend.

Svetlana Shasherina Slavistický ústav Jána Stanislava SAV Bratislava Slovensko svetlana.saserina@savba.sk 